\title{
ANALYSIS OF THE EQUIPMENT OPERATION SYSTEM IN TERMS OF AVAILABILITY
}

\section{ANALIZA SYSTEMU EKSPLOATACJI Z PUNKTU WIDZENIA GOTOWOŚCI}

\author{
Józef Żurek ${ }^{1)}$, Justyna Tomaszewska ${ }^{2)}$ \\ 1) Air Force Institute of Technology \\ ${ }^{2)}$ Polish Air Force Academy \\ e-mail: jozef.zurek@itwl.pl; j.tomaszewska@wsosp.pl
}

\begin{abstract}
In the article the process of operating a set of aircraft put into service at one time is examined. In order to maintain a balanced ratio ready to use and avoid the accumulation of hangar's maintenance, analysed transient process operation determining the probability of objects reside in different operating states. An interesting issue is change of a readiness as dependence of the model of adopted qualification.The main result of this article is the value of the probability of being ready to use. The probability of reaching the limit value is assuming different depends on initial conditions and different models of the probability density distributions.The results indicate the need for further testing of models of probability distributions to determine the optimal method qualifications or technical object is in standby mode or not.
\end{abstract}

Keywords: the process of exploitation, probability of the object

Streszczenie: $W$ artykule badany jest proces eksploatacji zbioru samolotów wprowadzanych do eksploatacji $w$ jednym czasie. $W$ celu utrzymania równomiernego wskaźnika gotowości do użycia $i$ uniknięcie spiętrzenia $w$ obshugach hangarowych, analizuje sie przebiegi przejściowe procesu eksploatacji wyznaczając prawdopodobieństwa przebywania obiektów $w$ poszczególnych stanach eksploatacyjnych. Interesujacym zagadnieniem sq zmiany gotowości $w$ zależności od przyjętego modelu kwalifikacyjnego. Jedna $z$ metod analitycznych opartych na analizie procesów losowych jest metoda procesów pótmarkowowskich (semi-Markowa). Bazuje ona na przyjęciu założenia, $\dot{z}$ e przebywanie obiektu technicznego w różnych stanach jest zmienna losowa. A jej wynikiem jest prawdopodobieństwo przebywania obiektu technicznego $w$ różnych stanach eksploatacyjnych $n p$. $w$ stanie gotowości. W pracy przedstawiono prawdopodobieństwa dojścia do stanu granicznego przy zatożeniu różnych stanów początkowych i uwzględnieniu stanu absorbcyjnego.

Stowa kluczowe: eksploatacja, niezawodność, gotowość 


\section{ANALYSIS OF THE EQUIPMENT OPERATION SYSTEM IN TERMS OF AVAILABILITY}

\section{Introduction}

The paper deals with investigation of processes associated with operating of a set of aircrafts that have been put into service at the same time. To achieve a balanced factor of equipment availability and to avoid piling up of maintenance and repair jobs in hangars, the transient processes associated with the aircraft operation have been analyzed with calculation of probabilities that specific aircrafts adopt one of various possible statuses under the assumption that intensities of transitions from one status to another are constant. An interesting issue is determination of moments when specific limits of probabilities are achieved when individual objects or group of objects are put into service.

\section{Semi-Markov processes}

Analytic methods based on analysis of stochastic processes include also an approach based on semi-Markov processes. The approach assumes that the probability that an object adopts a specific status is a random variable. These probabilities can be calculated with use of Mathematica software package. To keep the availability factor uniform for all equipment (each equipment piece is ready to use with the same probability) and to avoid overlapping of deadlines for maintenance staff working on hangars the set of aircrafts is split into some subsets that make up selected operational modules and are put in service one after another. It is assumed that an average aircraft within the module in question may adopt one of the following operational statuses: $S_{1}-$ waiting (standby); $S_{2}-$ pre-mission maintenance; $S_{3}$ - mission (in flight); $S_{4}$ - post-mission maintenance; $S_{5}$ - repairs and maintenance in hangars; $S_{6}-$ status of total destruction (terminal status). Adoption of statuses $S_{1}, S_{2}$ and $S_{3}$ by aircrafts is considered as the status of availability for use.

With the assumption that at any specific moment of time the aircraft can adopt one of possible statuses, e.g. "pre-mission maintenance" ( $S_{i}$ status) it can discretely move to another status, e.g. 'waiting (standby) $\left(S_{j}\right)$. Time of dwelling in the $S_{i}$ status prior to transition to the $S_{j}$ status is a random variable with a whichever distribution defined by the distribution function of $G_{i j}(t)$ and the transition from the $i^{t h}$ status to the $j^{\text {th }}$ status take place with the probability $p_{i j}>0$ (whereas $\sum_{i j} p=1$ ).

Next, if the transition from the status $S_{j}$ to the status $S_{k}$ occurs, the dwelling time of the status $S_{j}$ is also a random variable with whichever distribution of continuous type defined down the positive semiaxis with the distribution function $G_{j k}(\mathrm{t})$ etc. 
The probability of transition from the status $S_{i}$ to the status $S_{j}(\mathrm{i} \neq \mathrm{j})$ during the time interval $\Delta t$ is described for the semi-Markov process with the following relationship:

$$
p_{i j}(t, t+\Delta t)=F_{i j}(t+\Delta t) \Pi_{i j}
$$

where:

$\mathrm{F}_{\mathrm{ij}}(\mathrm{t})=\mathrm{P}\left\{\Theta_{\mathrm{ij}}<t\right\}-$ distribution function for the process dwelling in the $S_{i}$ status provided that the subsequent status is $S_{j}$

$\Pi_{i j}$ - conditional probability embedded into the Markov chain (probability of discrete transition to the status $S_{j}$ after the object leaves the status of $S_{i}$ ) [3],

$\Theta_{\mathrm{ij}}-$ random time variable of the process dwelling in the status $S_{i}$ provided that the subsequent status $S_{j}$.

\section{Model of operational statuses}

Attention in this study is focused on the model of aircraft operational statuses presented in the form of a directional graph (Fig. 1). This model additionally considers the status $S_{6}$ associated with full destruction of the technical object, i.e. the terminal status that is a very specific one in terms of the fact that it should be the dominating status within the sufficiently long horizon of operation time.

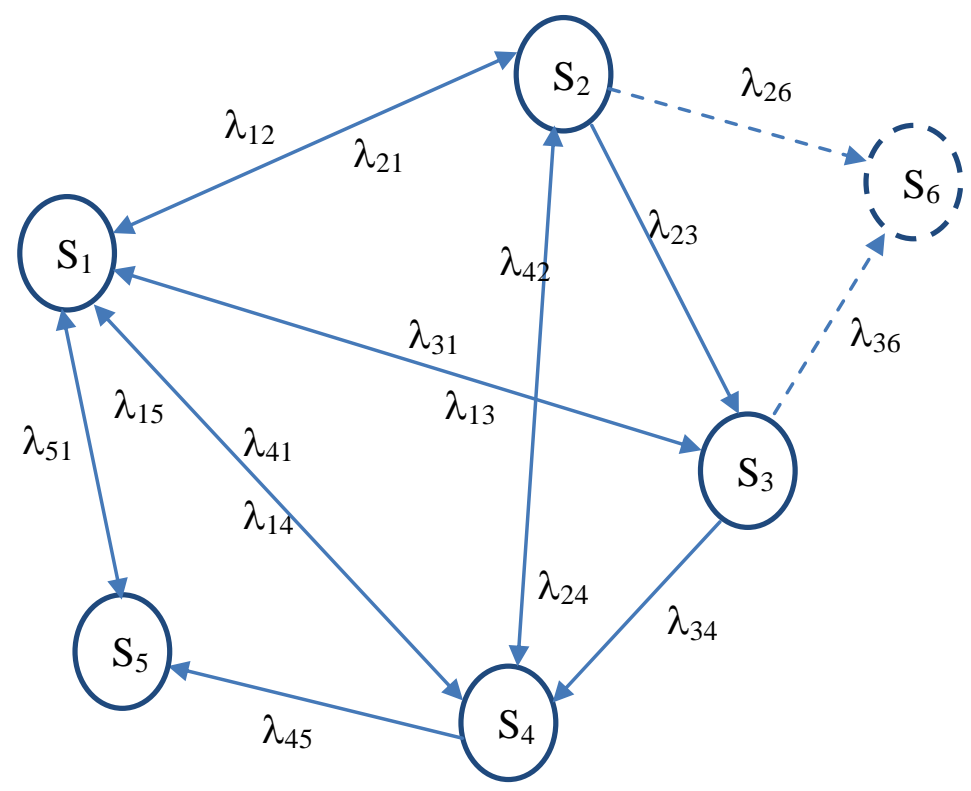

Fig. 1.: Directional graph for statuses of an aircraft operation. 
Analysis of the equipment operation system in terms of availability Analiza systemu eksploatacji z punktu widzenia gotowości

The system presented in Fig. 1 can be also described by means of a Kolmogorov system of differential equations (Borgoń, Jaźwiński, Klimaszewski, Żmudziński and Żurek, 1998):

$$
\begin{gathered}
\frac{d \mathrm{P}_{1}(\mathrm{t})}{\mathrm{dt}}=-\left(\lambda_{12}+\lambda_{13}+\lambda_{14}+\lambda_{15}\right) \mathrm{P}_{1}(\mathrm{t})+\lambda_{21} \mathrm{P}_{2}(\mathrm{t})+\lambda_{31} \mathrm{P}_{3}(\mathrm{t})+\lambda_{41} \mathrm{P}_{4}(\mathrm{t})+\lambda_{51} \mathrm{P}_{5}(\mathrm{t}) \\
\frac{\mathrm{dP}(\mathrm{t})}{\mathrm{dt}}=-\left(\lambda_{21}+\lambda_{23}+\lambda_{24}+\lambda_{26}\right) \mathrm{P}_{2}(\mathrm{t})+\lambda_{12} \mathrm{P}_{1}(\mathrm{t})+\lambda_{42} \mathrm{P}_{4}(\mathrm{t}) \\
\frac{\mathrm{dP}(\mathrm{t})}{\mathrm{dt}}=-\left(\lambda_{31}+\lambda_{34}+\lambda_{36}\right) \mathrm{P}_{3}(\mathrm{t})+\lambda_{13} \mathrm{P}_{1}(\mathrm{t})+\lambda_{23} \mathrm{P}_{2}(\mathrm{t}) \\
\frac{\mathrm{dP}(\mathrm{t})}{\mathrm{dt}}=-\left(\lambda_{41}+\lambda_{42}+\lambda_{45}\right) \mathrm{P}_{4}(\mathrm{t})+\lambda_{14} \mathrm{P}_{1}(\mathrm{t})+\lambda_{24} \mathrm{P}_{2}(\mathrm{t})+\lambda_{34} \mathrm{P}_{3}(\mathrm{t}) \\
\frac{\mathrm{dP}_{5}(\mathrm{t})}{\mathrm{dt}}=-\left(\lambda_{51}\right) \mathrm{P}_{5}(\mathrm{t})+\lambda_{15} \mathrm{P}_{1}(\mathrm{t})+\lambda_{45} \mathrm{P}_{4}(\mathrm{t}) \\
\frac{\mathrm{dP}(\mathrm{t})}{\mathrm{dt}}=\lambda_{26} \mathrm{P}_{1}(\mathrm{t})+\lambda_{36} \mathrm{P}_{4}(\mathrm{t})
\end{gathered}
$$

where the following symbols stand for the probabilities of individual statuses:

- $\mathrm{P}_{1}(\mathrm{t})$ - system adopts the status 'waiting (standby)'

- $\mathrm{P}_{2}(\mathrm{t})$ - system adopts the status 'pre-mission maintenance';

- $P_{3}(t)$ - system adopts the status 'mission (in flight)';

- $\mathrm{P}_{4}(\mathrm{t})$ - system adopts the status 'post-mission maintenance';

- $P_{5}(t)$ - system adopts the status 'repairs and maintenance in hangars';

- $\mathrm{P}_{6}(\mathrm{t})$ - system adopts the status 'total destruction';

$\lambda_{\mathrm{ij}}$ - intensity of transitions from the $i^{\text {th }}$ status to the $j^{\text {th }}$ status expressed as the transition frequency (number of transitions per hour), (i, $j) \in\{1,2,3,4,5,6\}$.

The $P_{6}(t)$ status should adopt the negigible intensity of $\lambda_{i j}$ within the considered (short) time horizon.

The matrix notation of the differential equations is the following (Paska \& Marchel):

$$
\begin{gathered}
\frac{d}{d t} P(t)=\Lambda P(t) \\
P(t)=\left[\begin{array}{l}
P_{1}(t) \\
P_{2}(t) \\
P_{3}(t) \\
P_{4}(t) \\
P_{5}(t) \\
P_{6}(t)
\end{array}\right],
\end{gathered}
$$


Józef Żurek, Justyna Tomaszewska

$\Lambda=\left[\begin{array}{cccccc}-\left(\lambda_{12}+\lambda_{13}+\lambda_{14}+\lambda_{15}\right) & \lambda_{21} & \lambda_{31} & \lambda_{41} & \lambda_{51} & 0 \\ \lambda_{12} & -\left(\lambda_{21}+\lambda_{23}+\lambda_{24}+\lambda_{26}\right) & 0 & \lambda_{42} & 0 & 0 \\ \lambda_{13} & \lambda_{23} & -\left(\lambda_{31}+\lambda_{34}+\lambda_{36}\right) & 0 & 0 & 0 \\ \lambda_{14} & \lambda_{24} & \lambda_{34} & -\left(\lambda_{41}+\lambda_{42}+\lambda_{45}\right) & 0 & 0 \\ \lambda_{15} & 0 & 0 & \lambda_{45} & -\lambda_{51} & 0 \\ 0 & \lambda_{26} & \lambda_{36} & 0 & 0 & 0\end{array}\right]$

Upon application of the Laplace transform the following system of linear equations is obtained:

$$
\begin{aligned}
& s P_{1}(t)-P_{1}(0)=-\left(\lambda_{12}+\lambda_{13}+\lambda_{14}+\lambda_{15}\right) P_{1}(t)+\lambda_{21} P_{2}(t)+\lambda_{31} P_{3}(t)+\lambda_{41} P_{4}(t)+\lambda_{51} P_{5}(t) \\
& P_{2}(t)-P_{2}(0)=-\left(\lambda_{21}+\lambda_{23}+\lambda_{24}+\lambda_{26}\right) P_{2}(t)+\lambda_{12} P_{1}(t)+\lambda_{42} P_{4}(t) \\
& s P_{3}(t)-P_{3}(0)=-\left(\lambda_{31}+\lambda_{34}+\lambda_{36}\right) P_{3}(t)+\lambda_{13} P_{1}(t)+\lambda_{23} P_{2}(t) \\
& s P_{4}(t)-P_{4}(0)=-\left(\lambda_{41}+\lambda_{42}+\lambda_{45}\right) P_{4}(t)+\lambda_{14} P_{1}(t)+\lambda_{24} P_{2}(t)+\lambda_{34} P_{3}(t) \\
& s P_{5}(t)-P_{5}(0)=-\left(\lambda_{51}\right) P_{5}(t)+\lambda_{15} P_{1}(t)+\lambda_{45} P_{4}(t) \\
& s P_{6}(t)-P_{6}(0)=\lambda_{26} P_{2}(t)+\lambda_{36} P_{3}(t)
\end{aligned}
$$

Table 1 summarizes intensities of transitions between individual statuses for actual processes of equipment operation.

Table 1: Intensities of transitions between individual statuses of equipment operation $\left[\frac{1}{\mathrm{~h}}\right]$.

\begin{tabular}{|c|c|c|c|c|c|c|}
\hline$\lambda_{\mathrm{ij}}$ & $\mathrm{S}_{1}$ & $\mathrm{~S}_{2}$ & $\mathrm{~S}_{3}$ & $\mathrm{~S}_{4}$ & $\mathrm{~S}_{5}$ & $\mathrm{~S}_{6}$ \\
\hline $\mathrm{S}_{1}$ & 0 & 0.001 & 0.01 & 0.009 & 0.02 & 0 \\
\hline $\mathrm{S}_{2}$ & 0.05 & 0 & 0 & 0.006 & 0 & 0 \\
\hline $\mathrm{S}_{3}$ & 0.09 & 0.09 & 0 & 0 & 0 & 0 \\
\hline $\mathrm{S}_{4}$ & 0.005 & 0.008 & 0.05 & 0 & 0 & 0 \\
\hline $\mathrm{S}_{5}$ & 0.001 & 0 & 0 & 0.001 & 0 & 0 \\
\hline $\mathrm{S}_{6}$ & 0 & 0.004 & 0.004 & 0 & 0 & 0 \\
\hline
\end{tabular}

\section{Determination of probability limits for semi-Markov processes}

At the initial moment the technical object under investigation can dwell in one of possible operational statuses that is referred to as the initial status of the object in question.

This analysis comprises computations ${ }^{1}$ how the probability that the object in question is dwelling in a specific status depends on time. This relationships is associated with initial conditions (initial status) of the object at the beginning.

\footnotetext{
${ }^{1}$ The computations were carried out with use of Mathematica software package where the solution was achieved as a combination of exponential functions with constant coefficients.
} 
Analysis of the equipment operation system in terms of availability Analiza systemu eksploatacji z punktu widzenia gotowości

The probabilities obtained for individual statuses under the assumption that the status of waiting is the initial one, is shown in Fig. 2, whilst the probability limits for each of the statuses are summarized in Table 2.

For comparison (Fig. 3), presents a model with the same levels of transition intensities but without consideration to the possibility that the aircraft can be totally destructed ${ }^{2}$. Comparison between these two models leads to the observation that for the model that takes account for the terminal status (Model 1) the time until the probability limits are achieved is much longer and the system tends to reach the dominating status that is the status of complete destruction. For Model 2 the final status is settled after about 100 days and the dominating status in 'repairs and maintenance in hangars.

Table 2 makes it possible to find out how the probability of the object dwelling in various operational statuses varies as a function of time. After about 100 days after the object is put into operation it amounts to $16 \%$ and is less than the corresponding level for Model 2. As the time goes by that parameter decreases to reach less than $1 \%$ after 10 years of the aircraft operation. The foregoing results encourage to investigate the availability factor (the aircraft is ready to fly) that seems to be an interesting topic.

Table 2. Probability limits for various operational statuses.

\begin{tabular}{|c|c|c|c|c|c|}
\hline \multirow{2}{*}{ Status } & \multirow{2}{*}{$\begin{array}{l}\text { Probability limit } \\
\text { without consideration } \\
\text { to the terminal } \\
\text { status [\%] }\end{array}$} & \multicolumn{4}{|c|}{$\begin{array}{c}\text { Probability [\%] of } \\
\text { dwelling in a status after }\end{array}$} \\
\hline & & $\begin{array}{l}100 \\
\text { days }\end{array}$ & $\begin{array}{l}365 \\
\text { days }\end{array}$ & $\begin{array}{l}1460 \\
\text { days }\end{array}$ & $\begin{array}{l}3650 \\
\text { days }\end{array}$ \\
\hline Waiting (standby) & 6 & 5 & 4 & 1 & 0.1 \\
\hline Pre-mission maintenance & 7 & 6 & 5 & 2 & 0.1 \\
\hline Mission (in flight) & 20 & 16 & 13 & 4 & 0.4 \\
\hline Post-mission maintenance & 64 & 55 & 45 & 14 & 1.4 \\
\hline $\begin{array}{l}\text { Repairs and maintenance } \\
\text { in hangars }\end{array}$ & 3 & 3.4 & 2.9 & 0.9 & 0.09 \\
\hline Total destruction & none & 13 & 29 & 78 & 98 \\
\hline
\end{tabular}

\footnotetext{
${ }^{2}$ Hereinafter in this study this model shall be referred to as Model 2 opposite to the model with consideration of the terminal status that is called Model 1.
} 


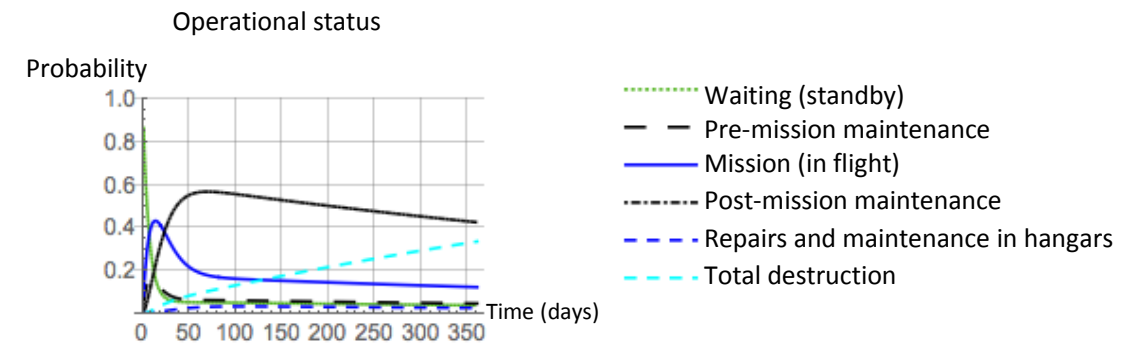

Probability
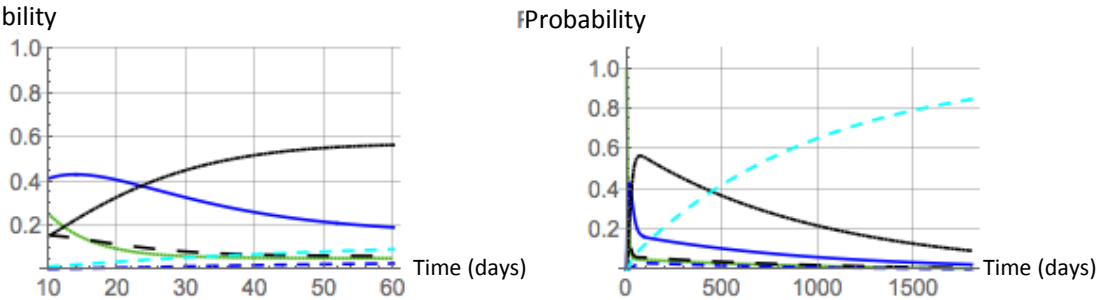

Fig. 2. Probability of the fact that a technical object adopts one of possible operational statuses provided that the waiting status is the initial one. The model assumes long time of equipment operation with final transition to the terminal status.

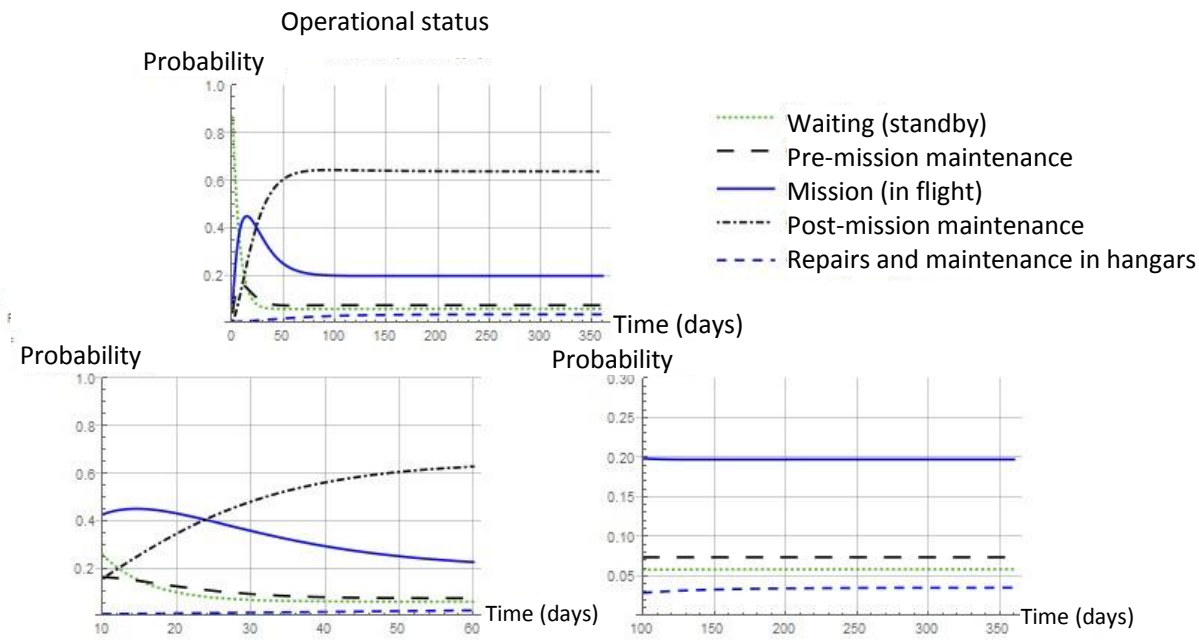

Fig. 3. Probability of the fact that a technical object adopts one of possible operational statuses provided that the waiting status is the initial one. The model assumes that transition can be effected from each status to at least one another status (no terminal status exists). 
Analysis of the equipment operation system in terms of availability Analiza systemu eksploatacji z punktu widzenia gotowości

\section{Availability factor (aircraft ready to fly)}

Evaluation of the object availability is intended to predict whether or not the specific technical object is available for future missions and enables execution of tasks. The availability factor can be calculated by means of the following relationship:

$$
K=\frac{p_{1}+p_{2}+p_{3}}{\sum_{i} p_{i}}, \quad \mathrm{i} \in\{1,2,3,4,5,6\}
$$

where:

$$
\begin{aligned}
i & - \text { probability that the object adopts the } i^{\text {th }} \text { operational status; } \\
p_{1}, p_{2}, p_{3}- & \text { probabilities that the object adopts any of the three statuses: } \\
& \text { "Waiting (standby)", „Pre-mission maintenance” or „Mission (in } \\
& \text { flight)". }
\end{aligned}
$$

For Model 2 it amounts to 33\% of availability that increases in pace with approval of subsequent subsets of technical object for operation. For Model 1 the availability (readiness to flights) without consideration to a special refurbishment procedures, decreases in time down to $27 \%$ (after 100 days) and to $1 \%$ after 10 years of operation.

\section{Conclusions}

Semi-Markov processes, upon fulfilment of specific assumptions, make it possible to determine probabilities of statuses to be reached by technical objects in question over a specific time horizon. The completed analysis explains how the process of the equipment operation looks like without undertaking special preventive measures when the post-mission maintenance tends to become the dominating status. In practice, when properly arranged and supervised corrective actions are in place and incorporated into the overall system of flight safety management, the process of equipment operation begins anew. The illustrative example of the process disclosed in this study also indicates consequences that may come true in case of negligence from the personnel responsible for safety of aircraft operation.

\section{References}

[1]Borgoń, J., Jaźwiński, J., Klimaszewski, S., Żmudziński, Z., i Żurek, J. Symulacyjne metody badania bezpieczeństwa lotów. Warszawa: Wydawnictwo Naukowe ASKON, 1998. (Simulative methods for investigation of flight safety, Warsaw, Scientific Publishing House ASKON, 1998).

[2]Paska, J., i Marchel, P. Wykorzystanie metod procesów Markowa i semiMarkowa w analizie niezawodności i systemów. Warszawa: Politechnika Warszawska. (Application of Markov and semi-Markov processes to analysis of reliability and system behaviour. Warsaw, University of Technology). 
[3] Grabski, F., Jaźwiński, J. Funkcje o losowych argumentach w zagadnieniach niezawodności, bezpieczeństwa i logistyki. Warszawa: Wydawnictwa Komunikacji i Łączności. 2009. (Functions with random arguments applicable to issues of reliability, safety and logistics, Warsaw, WKiE, 2009).

Prof. Józef Żurek - nominated professor of the Air Force Institute of Technology (ITWL). Chairman of the Scientific Council of the Institute, graduated the Military University of Technology (WAT) and majored in construction of aircraft engines. Currently involved in such fields as Design and Operation of Machinery and Transportation Means, in particular Reliability and Safety of Aircraft Technology (Share 50\%).

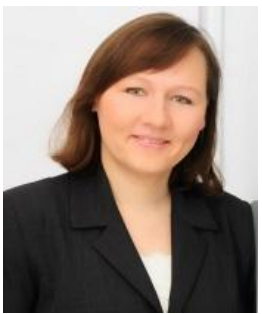

Justyna Tomaszewska, PhD, is employed as adjunct at the Air Force High School (WSSP) in Dęblin. Graduated the Faculty of Physics at Warsaw University in the field of elementary particles and has majored in statistic methods and mathematical modelling of technical systems, in particular in terms of reliability (Share 50\%). 
Analysis of the equipment operation system in terms of availability Analiza systemu eksploatacji z punktu widzenia gotowości

\section{ANALIZA SYSTEMU EKSPLOATACJI Z PUNKTU WIDZENIA GOTOWOŚCI}

\section{Wprowadzenie}

W artykule badany jest proces eksploatacji zbioru samolotów wprowadzanych do eksploatacji w jednym czasie. W celu utrzymania równomiernego wskaźnika gotowości do użycia i uniknięcie spiętrzenia w obsługach hangarowych, analizuje się przebiegi przejściowe procesu eksploatacji wyznaczając prawdopodobieństwa przebywania obiektów w poszczególnych stanach eksploatacyjnych, przy założeniu stałych intensywności przejść między stanami. Interesującym zagadnieniem są momenty osiągania prawdopodobieństw granicznych, w których wprowadza się do użytkowania poszczególne obiekty lub grupy obiektów.

\section{Procesy półmarkowowskie}

Jedną z metod analitycznych opartych na analizie procesów losowych jest metoda procesów półmarkowowskich (semi-Markowa). Bazuje ona na przyjęciu założenia, że przebywanie obiektu technicznego $\mathrm{w}$ różnych stanach jest zmienną losową. Wyznaczenie prawdopodobieństw można wykonać przy użyciu programu Matematica. Ze względu na utrzymanie równomiernego wskaźnika gotowości do użycia i uniknięcia spiętrzenia w obsługach hangarowych, zbiór samolotów rozdziela się na podzbiory stanowiące wybrane moduły operacyjne i stopniowo wprowadza się je do użytkowania. Zakłada się, że uśredniony samolot w rozpatrywanym module może przebywać w jednym ze stanów eksploatacyjnych: $S_{1}$ - oczekiwanie; $S_{2}$ - obsługa przed lotem; $S_{3}-1$ lot; $S_{4}$ - obsługa po locie; $\mathrm{S}_{5}$ - obsługa hangarowa; $\mathrm{S}_{6}-$ stan całkowitego zniszczenia (stan absorpcyjny). Przebywanie samolotu w stanach: $\mathrm{S}_{1}, \mathrm{~S}_{2 \mathrm{i}} \mathrm{S}_{3}$, zaliczamy do stanów gotowości.

Jeżeli założyć, że w danym momencie czasu samolot znajdował się w jednym ze stanów, np. w stanie "obsługa przed lotem" (stan $S_{i}$ ) to z tego stanu może przejść skokowo do innego stanu, np. do stanu oczekiwania $\left(S_{j}\right)$. Czas przebywania w stanie $S_{i}$ do przejścia do stanu $S_{j}$ jest zmienną losową o dowolnym rozkładzie opisywanym przez dystrybuantę $G_{i j}(t)$; przejście ze stanu $i$ do stanu $j$ zachodzi z prawdopodobieństwem $p_{i j}>0$ (przy czym $\sum_{i j} p=1$ ), jeżeli następnie nastąpi przejście ze stany $S_{j}$ do stanu $S_{k}$, to czas przebywania w stanie $S_{j}$ jest zmienną losową o dowolnym rozkładzie typu ciągłego opisanym na dodatniej półosi opisywanym dystrybuantą $G_{j k}(\mathrm{t})$ itd. 
Prawdopodobieństwa przejścia ze stanu $S_{i}$ do stanu $S_{j}(i \neq j)$ w przedziale czasu $\Delta t$ dla procesu semi-Markowa określone jest zależnością:

$$
p_{i j}(t, t+\Delta t)=F_{i j}(t+\Delta t) \Pi_{i j},
$$

gdzie:

$$
\begin{aligned}
F_{i j}(t)=P\left\{\Theta_{i j}<t\right\}- & \text { dystrybuanta czasu przebywania procesu w stanie } S_{i} \text { pod } \\
& \text { warunkiem, że następnym stanem będzie } S_{j}, \\
\Pi_{i j}- & \text { warunkowe prawdopodobieństwa włożonego w proces } \\
& \text { tańcucha Markowa (prawdopodobieństwa przejścia } \\
& \text { skokowego do stanu } S_{j} \text { przy wyjściu procesu } \\
& \text { ze stanu } \left.S_{i}\right)[3], \\
\Theta_{i j}- & \text { zmienna losowa czasu przebywania procesu w stanie } S_{i} \\
& \text { pod warunkiem, że następnym stanem będzie } S_{j} .
\end{aligned}
$$

\section{Model stanów eksploatacji}

W niniejszej pracy zajmiemy się modelem stanów eksploatacji samolotu przedstawionym $\mathrm{w}$ postacji grafu skierowanego (rys. 1). W modelu tym został dodatkowo uwyględniony stan $\mathrm{S}_{6}$, całkowitego zniczenia obiektu technicznego tzw. stan absorbcyjny, charakteryzujący się tym, że w odpowiednio długiej skali czasowej powinien być stanem dominującym.

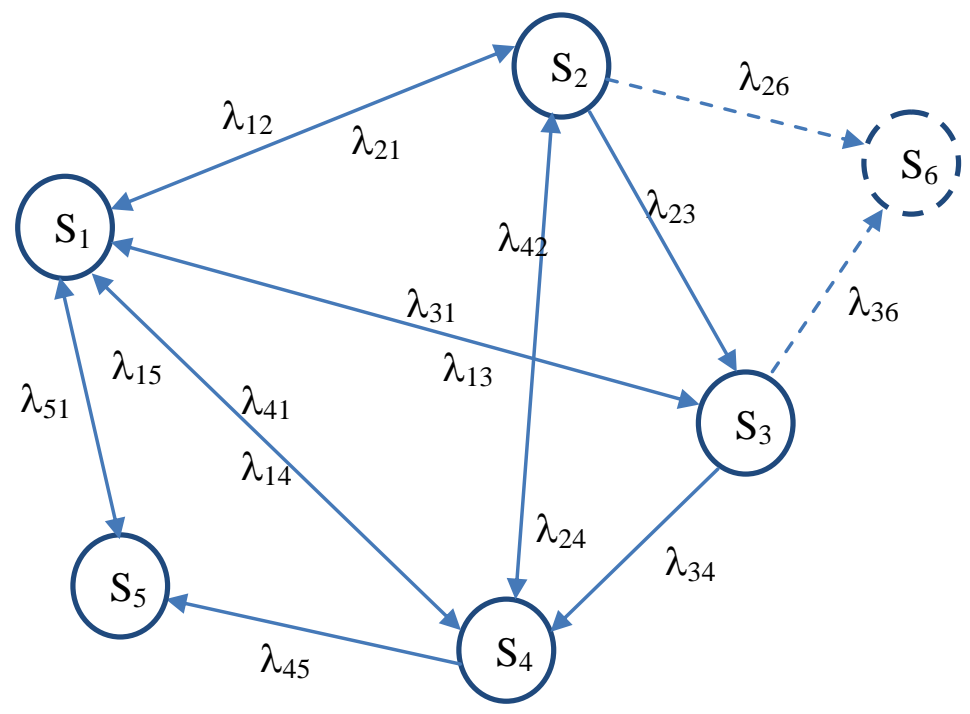

Rys. 1. Graf skierowany stanów eksploatacyjnych samolotu. 
Analysis of the equipment operation system in terms of availability Analiza systemu eksploatacji z punktu widzenia gotowości

System przedstawiony na rysunku 1 może być opisany układem równań różniczkowych Kołmogorowa (Borgoń, Jaźwiński, Klimaszewski, Żmudziński, Żurek 1998):

$$
\begin{gathered}
\frac{d \mathrm{P}_{1}(\mathrm{t})}{\mathrm{dt}}=-\left(\lambda_{12}+\lambda_{13}+\lambda_{14}+\lambda_{15}\right) \mathrm{P}_{1}(\mathrm{t})+\lambda_{21} \mathrm{P}_{2}(\mathrm{t})+\lambda_{31} \mathrm{P}_{3}(\mathrm{t})+\lambda_{41} \mathrm{P}_{4}(\mathrm{t})+\lambda_{51} \mathrm{P}_{5}(\mathrm{t}) \\
\frac{\mathrm{dP} \mathrm{P}_{2}(\mathrm{t})}{\mathrm{dt}}=-\left(\lambda_{21}+\lambda_{23}+\lambda_{24}+\lambda_{26}\right) \mathrm{P}_{2}(\mathrm{t})+\lambda_{12} \mathrm{P}_{1}(\mathrm{t})+\lambda_{42} \mathrm{P}_{4}(\mathrm{t}) \\
\frac{\mathrm{dP}(\mathrm{t})}{\mathrm{dt}}=-\left(\lambda_{31}+\lambda_{34}+\lambda_{36}\right) \mathrm{P}_{3}(\mathrm{t})+\lambda_{13} \mathrm{P}_{1}(\mathrm{t})+\lambda_{23} \mathrm{P}_{2}(\mathrm{t}) \\
\frac{\mathrm{dP}_{4}(\mathrm{t})}{\mathrm{dt}}=-\left(\lambda_{41}+\lambda_{42}+\lambda_{45}\right) \mathrm{P}_{4}(\mathrm{t})+\lambda_{14} \mathrm{P}_{1}(\mathrm{t})+\lambda_{24} \mathrm{P}_{2}(\mathrm{t})+\lambda_{34} \mathrm{P}_{3}(\mathrm{t}) \\
\frac{\mathrm{dP}_{5}(\mathrm{t})}{\mathrm{dt}}=-\left(\lambda_{51}\right) \mathrm{P}_{5}(\mathrm{t})+\lambda_{15} \mathrm{P}_{1}(\mathrm{t})+\lambda_{45} \mathrm{P}_{4}(\mathrm{t}) \\
\frac{\mathrm{dP}}{\mathrm{dt}}(\mathrm{t}) \\
=\lambda_{26} \mathrm{P}_{1}(\mathrm{t})+\lambda_{36} \mathrm{P}_{4}(\mathrm{t})
\end{gathered}
$$

gdzie poniższe symbole oznaczają prawdopodobieństwa:

- $\mathrm{P}_{1}(\mathrm{t})$ - przebywania systemu $\mathrm{w}$ stanie ,oczekiwania”;

- $\mathrm{P}_{2}(\mathrm{t})$ - przebywania systemu w stanie „obsługi przed lotem”;

- $\mathrm{P}_{3}(\mathrm{t})$ - przebywania systemu w stanie „lot”;

- $\mathrm{P}_{4}(\mathrm{t})$ - przebywania systemu $\mathrm{w}$ stanie ,obsługi po locie”;

- $\mathrm{P}_{5}(\mathrm{t})$ - przebywania systemu w stanie „obsługa hangarowa”;

- $\mathrm{P}_{6}(\mathrm{t})$ - przebywania systemu $\mathrm{w}$ stanie „,całkowitego zniszczenia”;

$\lambda_{i j}$ - intensywność przejścia ze stanu $i$ do stanu $j$, wyrażona częstością przejść na godz., $(i, j) \in\{1,2,3,4,5,6\}$.

Stan $P_{6}(t)$ w rozpatrywanym (krótszym horyzoncie czasowym może posiadać zaniedbywalnie małą intensywność $\lambda_{i j}$.

Zapis macierzowy (Paska i Marchel) jest następujący:

$$
\begin{gathered}
\frac{d}{d t} P(t)=\Lambda P(t) \\
P(t)=\left[\begin{array}{l}
P_{1}(t) \\
P_{2}(t) \\
P_{3}(t) \\
P_{4}(t) \\
P_{5}(t) \\
P_{6}(t)
\end{array}\right],
\end{gathered}
$$




$$
\Lambda=\left[\begin{array}{cccccc}
-\left(\lambda_{12}+\lambda_{13}+\lambda_{14}+\lambda_{15}\right) & \lambda_{21} & \lambda_{31} & \lambda_{41} & \lambda_{51} & 0 \\
\lambda_{12} & -\left(\lambda_{21}+\lambda_{23}+\lambda_{24}+\lambda_{26}\right) & 0 & \lambda_{42} & 0 & 0 \\
\lambda_{13} & \lambda_{23} & -\left(\lambda_{31}+\lambda_{34}+\lambda_{36}\right) & 0 & 0 & 0 \\
\lambda_{14} & \lambda_{24} & \lambda_{34} & -\left(\lambda_{41}+\lambda_{42}+\lambda_{45}\right) & 0 & 0 \\
\lambda_{15} & 0 & 0 & \lambda_{45} & -\lambda_{51} & 0 \\
0 & \lambda_{26} & \lambda_{36} & 0 & 0 & 0
\end{array}\right]
$$

Używając przekształcenia Laplace’a uzyskano układ równań w postaci:

$$
\begin{aligned}
& s P_{1}(t)-P_{1}(0)=-\left(\lambda_{12}+\lambda_{13}+\lambda_{14}+\lambda_{15}\right) P_{1}(t)+\lambda_{21} P_{2}(t)+\lambda_{31} P_{3}(t)+\lambda_{41} P_{4}(t)+\lambda_{51} P_{5}(t) \\
& P_{2}(t)-P_{2}(0)=-\left(\lambda_{21}+\lambda_{23}+\lambda_{24}+\lambda_{26}\right) P_{2}(t)+\lambda_{12} P_{1}(t)+\lambda_{42} P_{4}(t) \\
& s P_{3}(t)-P_{3}(0)=-\left(\lambda_{31}+\lambda_{34}+\lambda_{36}\right) P_{3}(t)+\lambda_{13} P_{1}(t)+\lambda_{23} P_{2}(t) \\
& s P_{4}(t)-P_{4}(0)=-\left(\lambda_{41}+\lambda_{42}+\lambda_{45}\right) P_{4}(t)+\lambda_{14} P_{1}(t)+\lambda_{24} P_{2}(t)+\lambda_{34} P_{3}(t) \\
& s P_{5}(t)-P_{5}(0)=-\left(\lambda_{51}\right) P_{5}(t)+\lambda_{15} P_{1}(t)+\lambda_{45} P_{4}(t) \\
& s P_{6}(t)-P_{6}(0)=\lambda_{26} P_{2}(t)+\lambda_{36} P_{3}(t)
\end{aligned}
$$

W tabeli 1 zestawiono intensywność przejścia pomiędzy poszczególnymi stanami dla rzeczywistego procesu eksploatacji.

Tab.1: Intensywność przejścia pomiędzy poszczególnymi stanami eksploatacyjnymi $\left[\frac{1}{\mathrm{~h}}\right]$.

$\begin{array}{ccccccc}\lambda_{\mathrm{ij}} & \mathrm{S}_{1} & \mathrm{~S}_{2} & \mathrm{~S}_{3} & \mathrm{~S}_{4} & \mathrm{~S}_{5} & \mathrm{~S}_{6} \\ \mathrm{~S}_{1} & 0 & 0,001 & 0,01 & 0,009 & 0,02 & 0 \\ \mathrm{~S}_{2} & 0,05 & 0 & 0 & 0,006 & 0 & 0 \\ \mathrm{~S}_{3} & 0,09 & 0,09 & 0 & 0 & 0 & 0 \\ \mathrm{~S}_{4} & 0,005 & 0,008 & 0,05 & 0 & 0 & 0 \\ \mathrm{~S}_{5} & 0,001 & 0 & 0 & 0,001 & 0 & 0 \\ \mathrm{~S}_{6} & 0 & 0,004 & 0,004 & 0 & 0 & 0\end{array}$

\section{Wyznaczanie prawdopodobieństw granicznych w procesach semi-markowa}

Badany obiekt techniczny może w chwili początkowej czasu znajdować się w jednym ze stanów eksploatacyjnych, który jest stanem początkowym badanego obiektu.

W niniejszej analizie policzono ${ }^{3}$ zależność prawdopodobieństwa przebywania $\mathrm{w}$ danym stanie $\mathrm{w}$ funkcji czasu. Zależność ta jest ściśle powiązana $\mathrm{z}$ warunkami początkowymi w jakich znajdował się nasz obiekt.

${ }^{3}$ Obliczeń dokonano w programie Mathematica, jako rozwiązanie układu otrzymano kombinację funkcji ekspotencjalnych ze stałymi współczynnikami. 
Analysis of the equipment operation system in terms of availability Analiza systemu eksploatacji z punktu widzenia gotowości

Otrzymane prawdopodobieństwa dla poszczególnych stanów, przy założeniu jako warunków początkowych stanu oczekiwania, w funkcji czasu przedstawiono na rysunku 2, zaś prawdopodobieństwo graniczne dla każdego ze stanów podsumowano w tabeli 2 .

Dla porównania na rysunku 3 przedstawiono model z tymi samymi wartościami intensywności przejść ale bez uwzględnienia całkowitej możliwości zniszczenia statku powietrznego ${ }^{4}$. Porównując te dwa model można zauważyć, że w modelu ze stanem absorpcyjnym (Model 1) czas osiągnięcia prawdopodobieństw granicznych jest dłuższy oraz istnieje tendencja, że stanem dominującym staje się stan całkowitego zniszczenia. Dla Modelu 2 stan graniczny ustala się po około 100 dniach i stanem dominującym jest obsługa hangarowa.

$\mathrm{Na}$ podstawie tabeli 2 można zauważyć jak zmienia się prawdopodobieństwo przebywania $\mathrm{w}$ różnych stanach eksploatacyjnych w funkcji czasu. Po około 100 dniach od wprowadzenia obiektu do eksploatacji wynosi ono $16 \%$ i jest mniejsze od wartości dla Modelu 2. Z czasem ta wartość maleje aby po 10 latach eksploatacji dojść do wartości poniżej 1\%. W świetle powyższych rozważań interesującą wartością jest współczynnik gotowości do lotu.

Tab. 2: Prawdopodobieństwo graniczne dla poszczególnych stanów eksploatacyjnych.

\begin{tabular}{|l|c|c|c|c|c|}
\hline \multirow{2}{*}{ Stan } & Prawdopodobieństwo & \multicolumn{4}{|c|}{ Prawdopodobieństwo [\%] } \\
& $\begin{array}{c}\text { graniczne bez } \\
\text { uwzględnienia stanu } \\
\text { absorpcyjnego [\%] }\end{array}$ & $\begin{array}{c}100 \\
\text { przebywania w danym stanie po }\end{array}$ \\
\cline { 3 - 6 } & 6 & 365 & $\begin{array}{c}1460 \\
\text { dniach }\end{array}$ & $\begin{array}{c}3650 \\
\text { dniach }\end{array}$ & dniach \\
\hline Oczekiwanie & 7 & 6 & 5 & 2 & 0,1 \\
\hline Obsługa przed lotem & 20 & 16 & 13 & 4 & 0,4 \\
\hline Lot & 64 & 55 & 45 & 14 & 1,4 \\
\hline Obsługa po locie & 3 & 3,4 & 2,9 & 0,9 & 0,09 \\
\hline Obsługa hangarowa & brak & 13 & 29 & 78 & 98 \\
\hline Całkowite zniszczenie & & & &
\end{tabular}

\section{Współczynnik gotowości do lotu}

Celem oceny gotowości do lotu jest najczęściej wyznaczenie prognozy, czy dany obiekt techniczny będzie znajdował się w stanie zdatności w przyszłości i czy umożliwi to realizację zadania. Gotowość tę można wyrazić za pomocą zależności

$$
K=\frac{p_{1}+p_{2}+p_{3}}{\sum_{i} p_{i}}, \quad \mathrm{i} \in\{1,2,3,4,5,6\}
$$

gdzie

$i$ - oznacza prawdopodobieństwo przebywania w $i$-tym stanie eksploatacyjnym,

$p_{l}, p_{2}, p_{3}$ - prawdopodobieństwo przebywania $\mathrm{w}$ trzech stanach „oczekiwanie”, „obsługa przed lotem”, „wykonywanie zadania (lot)”

\footnotetext{
${ }^{4} \mathrm{~W}$ dalszej części pracy model ten będzie nazywany Model 2, dla rozróżnienia od modelu ze stanem absorpcyjnym Model 1 .
} 
Dla Model 2 oznacza to 33\% gotowości, która wzrasta wraz z dopuszczaniem do zadań obiektów technicznych w grupach. Dla Modelu 1 gotowość do lotu, bez uwzględnienia specjalnego zabiegu odnowy, maleje wraz z upływem czasu od $27 \%$ (po upływie 100 dni) do ok. 1\% po 10 latach eksploatacji.
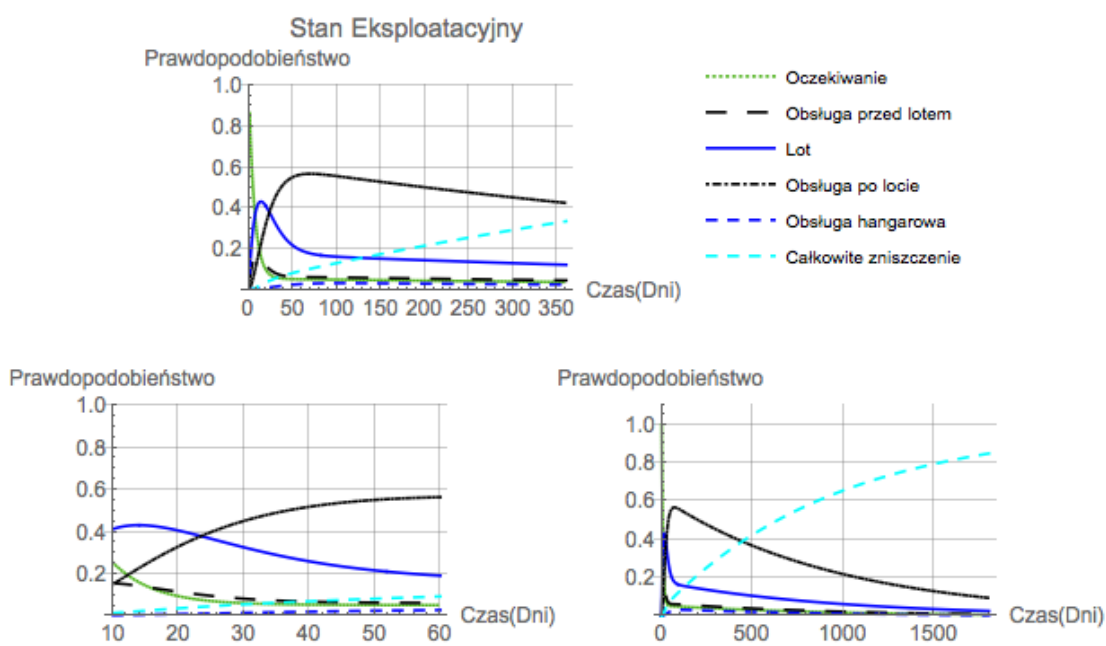

Rys. 4. Prawdopodobieństwo przebywania obiektu technicznego w jednym ze stanów eksploatacyjnych, przy założeniu, że stanem poczatkowym byt stan oczekiwania. Model uwzględnia, dtugi czas trwania procesu eksploatacji z przejściem do stanu absorpcyjnego.

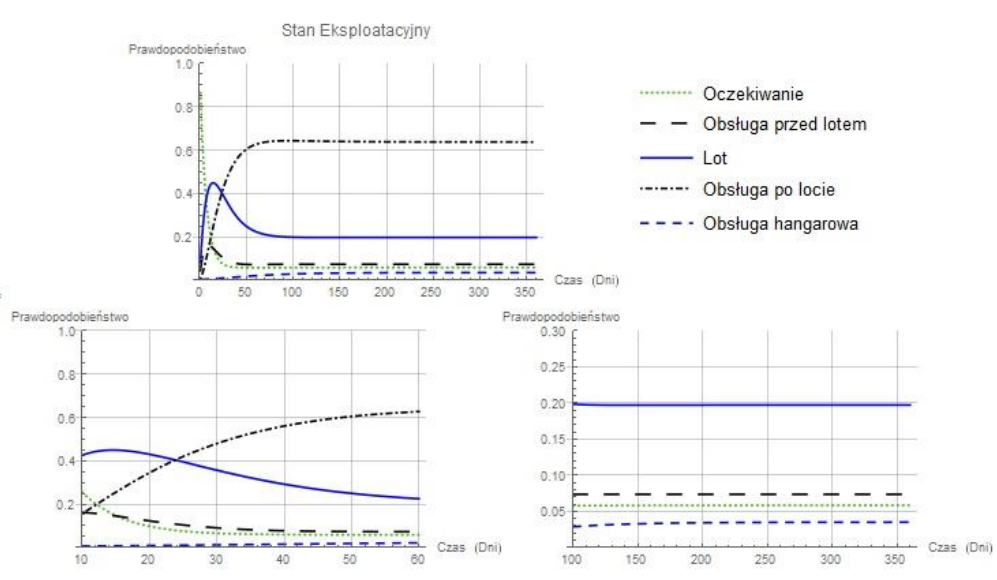

Rys. 3. Prawdopodobieństwo przebywania obiektu technicznego w jednym ze stanów eksploatacyjnych, przy założeniu, że stanem poczatkowym byt stan oczekiwania. Model zakłada, że z każdego stanu można przejść przynajmniej do jednego innego stanu (brak stanu absorpcyjnego). 
Analysis of the equipment operation system in terms of availability Analiza systemu eksploatacji z punktu widzenia gotowości

\section{Wnioski}

Procesy semi-Markowa, przy spełnionych założeniach pozwalają wyznaczać prawdopodobieństwa $\mathrm{w}$ jakim stanie znajduje się analizowany obiekt techniczny w rozpatrywanym przedziale czasowym. Przeprowadzona analiza wyjaśnia jak przebiega proces eksploatacji bez uwzględnienia specjalnych zabiegów profilaktycznych gdy dominującym stanem okazuje się obsługa po locie. W praktyce po wprowadzeniu odpowiednio zaprojektowanych i nadzorowanych przez system zarządzania bezpieczeństwem lotów przedsięwzięć korygujących proces eksploatacji system zaczyn proces od nowa. Przedstawiona $\mathrm{w}$ artykule ilustracja procesu przedstawia przewidywane skutki zaniedbań nadzoru służb bezpieczeństwa lotów.

\section{Bibliografia}

[1] Borgoń, J., Jaźwiński, J., Klimaszewski, S., Żmudziński, Z., i Żurek, J. Symulacyjne metody badania bezpieczeństwa lotów. Warszawa: Wydawnictwo Naukowe ASKON, 1998.

[2] Paska, J., i Marchel, P. Wykorzystanie metod procesów Markowa i semi-Markowa w analizie niezawodności i systemów. Warszawa: Politechnika Warszawska.

[3] Grabski, F., Jaźwiński, J. Funkcje o losowych argumentach w zagadnieniach niezawodności,bezpieczenstwie i logistyki. Warszawa: Wydawnictwa Komunikacji i Łączności. 2009.

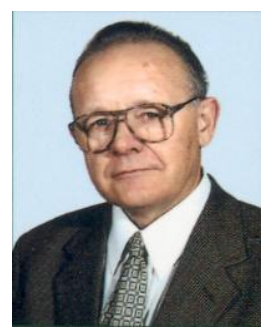

Prof. Józef Żurek - profesor zwyczajny Instytutu Technicznego Wojsk Lotniczych. Przewodniczacy Rady Naukowej ITWL. ukończyt Wojskowa Akademie Techniczna, specjalność: budowa samolotów $i$ silników lotniczych. A|ktualne dziedziny działalności, to Budowa i Eksploatacja Maszyn oraz Transport, a w szczególności Niezawodność i Bezpieczeństwo Techniki Lotniczej (Udział 50\%).

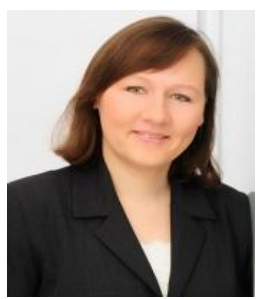

dr Justyna Tomaszewska pracuje jako adiunkt w Wyższej Szkole Sit Powietrznych $w$ Dęblinie. Ukończyla Wydziat Fizyki na Uniwersytecie Warszawskim $w$ dziedzinie czastek elementarnych. Naukowe zainteresowania to metody statystyczne I modelowanie matematyczne systemów technicznych zwlaszcza z punktu widzenia niezawodności (Udziat 50\%). 